\title{
Risk of Transfusion-Transmitted Human Parvovirus B19 Infection in Anyigba and Lokoja, Kogi State - Nigeria
}

\author{
Musa, Sunday A. U. ${ }^{1,3}$; Prof. Banwat, Edmund B. ${ }^{1}$; Zhakom Ponfa ${ }^{2}$; Rumji, \\ Elisha M. $^{2}$; Yakubu, Rebecca K. ${ }^{2}$ and Rufai, Olalekan A. ${ }^{2}$ \\ ${ }^{1,}$ Department Of Medical Microbiology, University Of Jos, P.M.B 2084 Jos, Postal Code: 930001, Plateau \\ State, Nigeria \\ ${ }^{2,}$ National Blood Transfusion Service, North-Central Zonal Centre, Plateau Specialist Hospital Premises, Jos \\ 3. ACET Nigeria Head Office, Flat 3, Floor 2, FCS National Secretariat Building, Opposite Building Materials \\ Market, Yakubu Gowon Way, P.O. Box 1347, Jos, Postal Code: 930001, Plateau State, Nigeria
}

\begin{abstract}
Background: Human parvovirus B19 (HPV-B19) has cosmopolitan distribution and can be transmitted parenterally by transfusion of infected blood or blood products. HPV-B19 screening of blood and blood products for transfusion is not done routinely in Nigeria. Concerns on the safety of blood transfusion in Kogi State, Nigeria informed this research.
\end{abstract}

Objective: To assess need to undertake routine screening of donor blood for the prevention of transfusion transmitted HPV-B19 infection in Kogi State, Nigeria.

Methods: Within the months of September to November, 2010, serum samples of eighty-eight blood donors at Grimad Catholic Hospital, Anyigba and Federal Medical Centre, Lokoja, Kogi State were tested for the presence of anti-B19 IgM and IgG antibodies using ELISA kits (ODemeditec Diagnostic, Germany).

Results: A total of 37(42.0\%) out of 88 blood donors screened in this research had anti-B19 antibodies (IgM and/or IgG) in their sera. 13(14.8\%) out of 88 blood donors were sero-positive for anti-B19 IgM antibody, indicative of recent infection. Three (75\%) out of the 4 paid blood donors in this research were sero-positive for anti-B19 IgM and $\operatorname{IgG}$ antibodies indicative of lower quality of paid donor blood.

Conclusion: This research showed that recipients of blood and blood products in Anyigba and Lokoja, Kogi State are at high risk $(\geq 14.8 \%)$ of transfusion transmitted HPV-B19 infection. The study therefore recommends routine screening of donor blood and blood products as a matter of urgent public health policy.

\section{INTODUCTION}

Human parvovirus B19 (HPV-B19) was discovered by chance during the screening of blood samples for hepatitis B surface antigen ${ }^{(3)}$. The virus is common throughout the world and has the potential to precipitate severe anaemia ${ }^{(9)}$. HPV-B19 is the only known parvovirus pathogenic for humans, and it has a tropism for erythroid progenitor cells. It is the cause of erythema infectiosum ("Fifth disease"), a common childhood exanthema; of a polyarthralgia-arthritis syndrome in normal adults; of aplastic crisis in patients with haemolytic disorders; of chronic anaemia in immunocompromised individuals; and of foetal death in pregnant women ${ }^{(1)}$.

HPV-B19 Infection can occur throughout the year, in all age groups, and as outbreaks or as sporadic cases. Many infections are subclinical. Estimates of attack rates in susceptible contacts range from 20 to $50 \%{ }^{(1)}$. About 30 to $60 \%$ of blood donors have antibodies to parvovirus B19 $9^{(7)}$. B19 can be transmitted parenterally by blood transfusion or by infected blood products (clotting and immunoglobulin concentrates) and vertically from mother to foetus ${ }^{(1)}$ during pregnancy. Both virus-specific IgM and IgG antibodies are made following B19 infections ${ }^{(6)}$.

Blood transfusion has proven to be an invaluable therapeutic technique for diverse kinds of anaemia as well as medical and surgical procedures involving haemorrhage. However, the need to ensure the safety of the blood or blood products as well as the procedures involved in any blood transfusion exercise cannot be overemphasised. Implementation of stringent donor eligibility criteria, improved donor screening and more sophisticated as well as sensitive methods of antibody, antigen and viral genome detection, have virtually eliminated transfusion transmitted infection in developed countries ${ }^{(7)}$. In developing countries including Nigeria, the risk of transfusion-transmitted infections is still considerable. B19 susceptible individuals including immunodeficient patients, patients with haemolytic anaemias, pregnant women and young children, are among the categories of people commonly requiring blood transfusion. In view of the cosmopolitan distribution of 
Parvovirus B19 and its transmissibility; parenterally by blood transfusion or by infected blood products and vertically from mother to foetus,

The Nigerian population can be said to be at risk of B19 infection. Yoto et al. (2008) recommended the screening of donor blood products for B19 DNA to prevent transfusion mediated viral infection for those susceptible such as immunocompromised patients and pregnant women. However, HPV-B19 screening of blood and blood products for transfusion is not done routinely in Nigeria. This research to assess need to undertake routine screening of donor blood for the prevention of transfusion transmitted HPV-B19 infection in Kogi State, Nigeria, is therefore of public health importance.

\subsection{Study Area}

\section{MATERIALS AND METHODS}

The research was conducted in two central towns in Kogi State, North Central Geopolitical Zone of Nigeria, namely: Anyigba in Kogi East Senatorial District; and Lokoja (State Capital) in Kogi West Senatorial District and is one of the most historic towns in Nigeria, where River Benue and River Niger confluence. Samples were collected at Grimad Catholic Hospital (GCH), Anyigba, a Christian mission hospital and Federal Medical Centre (FMC), a tertiary health institution. The blood banks of these hospitals serve patients from all parts of the state and some five neighbouring states directly; the towns being junction towns linking south, west and eastern parts of Nigeria with the Federal Capital Territory - Abuja, also make these hospitals of national importance. Samples were assayed at the National Blood Transfusion Service, North-Central Zonal Centre, Jos.

\subsection{Study Population}

Male and female individuals, 18 years and above, willing to donate blood or blood products for transfusion at the two hospitals in the months of September to November, 2010, who consented to participate in the survey were recruited in the research irrespective of their status as voluntary or paid donors. A total of eighty-eight donor samples were collected and analysed.

\subsection{Survey and Laboratory Assays}

A written informed consent was sought and obtained from all the blood donors before inclusion in the study. The demographic data and other relevant information of each participant were obtained using a questionnaire. Three millilitres ( $3 \mathrm{mls})$ of venous blood was aseptically collected from each study participant into a clean, sterile plain plastic container. The blood sample was allowed to clot naturally in a refrigerator at $4^{\circ} \mathrm{C}$. The blood sample was centrifuged at $1500 \mathrm{rpm}$ after dislodging the clot. Serum specimen was extracted from the blood sample and frozen at $-20^{\circ} \mathrm{C}$. The serum specimens were transported frozen within 12 hours with the aid of iceboxes from Anyigba and Lokoja to the National Blood Transfusion Service Centre in Jos and kept frozen at $-20^{\circ} \mathrm{C}$ until the point of serological assays. The fourth generation enzyme-linked immunosorbent assay (ELISA) method ( ${ }^{\circ}$ Demeditec Diagnostic, Germany, 2010; 2011) was used for detection of anti-B19 IgM and IgG antibodies. Assays were carried out and interpreted based on manufacturer's instructional manual.

\subsection{Ethical Consideration}

Ethical clearance for the study was obtained from each of the two medical centres where the study was conducted and the National Blood Transfusion Service, North Central Zonal Centre - Jos, where the assay was run. The study was conducted in accordance with international standards for medical research.

\subsection{Data Analysis}

Absorbance readings were taking with calculations effected according to manufacturer's instructions by automated ELISA devices/software in the ELISA equipment (Start Fax-2100, Awareness Technology Inc). The research results were analysed using the Statistical Package for Social Sciences (SPSS) Version 17 (@20032007 by Polar Engineering and Consulting). Chi-square test was carried out on the various parameters using Pearson's correlation to evaluate relationships.

\subsection{RESULTS}

A total of 88 blood donors composed of $84(95.5 \%)$ voluntary donors and 4(4.5\%) paid blood donors participated in the study, of whom 83(94.3\%) were males and 5(5.7\%) females. Overall, 37(42.0\%) out of 88 blood donors tested in this research had either or both anti-B19 IgM and IgG antibodies in their sera. 33(37.5\%) out of 88 blood donors were sero-positive for anti-B19 IgG antibody, while 13(14.8\%) were sero-positive for anti-B19 IgM antibody.13(15.7\%) out of 83 males were sero-positive for anti-B19 IgM antibodies, while no female was sero-positive. 32(38.6\%) of males and 1(20\%) of the 5 females were sero-positive for anti-B19 IgG antibody. Males had higher within sex sero-prevalence of $38.6 \%$ compared to $20 \%$ for females for IgG. Sex however, had no statistically significant effect on the sero-prevalence of B19 antibodies among blood donors in this study $(\mathrm{P}>0.05$; Table 1$)$. 
Participants with 20-29 age bracket had higher within age B19 sero-prevalence of 55.7\% compared to $41.9 \%$ of ages $30-39$ and $33.3 \%$ of ages 50-59. For anti-B19 IgM antibody, the 50-59 age bracket had higher within age sero-prevalence of $33.3 \%$ compared to $16.1 \%$ of $30-39$ and $15.6 \%$ of ages $20-29$. Age however, had no statistically significant effect on B19 sero-prevalence among the blood donors tested (P>0.05; Table 2).3(75\%) out of the 4 paid blood donors in the research were sero-positive for both anti-B19 $\operatorname{IgM}$ and $\operatorname{IgG}$ antibodies. Paid blood donors had higher within status sero-prevalence of $75.0 \%$ compared to $40.5 \%$ among voluntary blood donors. Blood donors' status as paid or voluntary donors was a significant determinant of recent HPV-B19 infection with higher within status prevalence of anti-B19 IgM antibody (50.0\%) among paid blood donors (Fig. 1).

Table 1: Sex Distribution of Anti-B19 antibodies among blood donors at Anyigba and Lokoja in Kogi State

\begin{tabular}{ccccc}
\hline Sex & $\begin{array}{c}\text { Number of Samples } \\
\text { Collected }\end{array}$ & $\begin{array}{c}\text { Number Positive for } \\
\text { IgM Antibody }\end{array}$ & $\begin{array}{c}\text { Number Positive for } \\
\text { IgG Antibody }\end{array}$ & $\begin{array}{c}\text { Number Positive for } \\
\text { IgM/IgG Abs }\end{array}$ \\
\hline Male & $83(94.3)$ & $13(15.7)$ & $32(38.6)$ & $36(43.4)$ \\
Female & $5(5.7)$ & $0(0.00)$ & $1(20.0)$ & $1(20.0)$ \\
\hline Total & $88(100)$ & $13(14.8)$ & $35(39.8)$ & $37(42.0)$ \\
\hline \multicolumn{2}{c}{ Statistical Values } & $\chi^{2}=0.9$ & $\chi^{2}=0.7$ & $\chi^{2}=1.1$ \\
& & $\mathrm{DF}=1$ & $\mathrm{DF}=1$ & $\mathrm{DF}=1$ \\
& & $\mathrm{P}>0.05$ & $\mathrm{P}>0.05$ & $\mathrm{P}>0.05$
\end{tabular}

Parenthesis $=$ Percent

Table 2: Age Distribution of Anti-B19 antibodies among blood donors at Anyigba and Lokoja in Kogi State

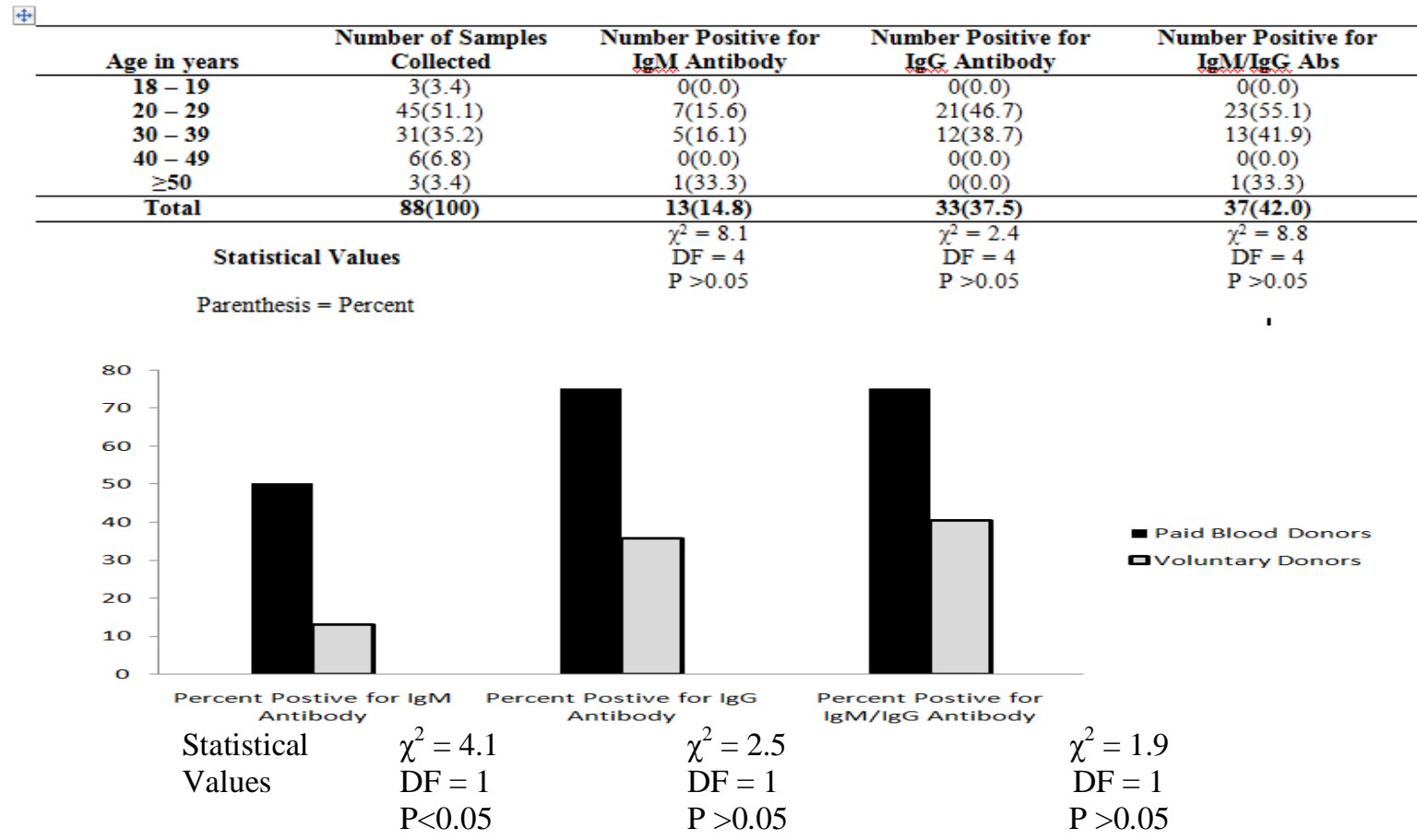

Fig. 1: Comparative sero-prevalence of HPV-B19 between paid and voluntary blood donors at Anyigba and Lokoja in Kogi State

\section{DISCUSSION}

Post-transfusion transmission of human parvovirus B19 is an established problem globally. Data on human parvovirus B19 infection in Nigeria and Africa at large are limited, which has serious public health implications. It was observed in this study, that a high percentage (14.8\%) of participants were sero-positive for anti-B19 $\operatorname{IgM}$ antibodies, indicative of recent infection and overall sero-prevalence ( $\operatorname{IgM} / \operatorname{IgG}$ antibodies) of $42.0 \%$. While the overall sero-prevalence is consistent with other studies in other parts of the world, such as Heegaard et al. (2002) in Copenhagen, Denmark with B19 seroprevalence range of 30-60\% in healthy adults, 
Kaur and Basu (2005) who estimated that 30-60\% of blood donors have antibodies ( $\operatorname{IgG}$ ) to B19, and Emiasegen et al. (2011) who reported 40.7\% HPV seroprevalence among pregnant women in an antenatal clinic in Jos, North Central Nigeria, the recent infection rate of $14.8 \%$ is rather higher than any other study to the best of the researcher's knowledge. Yoto et al., 2008 reported 6(0.6\%) of 1000 serum samples from blood donors that were tested for human parvovirus B19 (B19) DNA by a nested PCR assay as positive for B19 DNA; five (83.3\%) of the six samples were also positive for anti-B19 IgM, indicating an acute phase of B19 infection among donors. The higher anti-B19 IgM antibody of $14.8 \%$ observed in this work compared to the work of Yoto et al., 2008 may be due to difference in sampling methods, population size and assay method (DNA test in their case). The lower immunity observed in this study is consistent with the work of Kishore et al. (2010), who reported a low sero-prevalence of $39.9 \%$ in a population of Indian blood donors, which led him to conclude that a large proportion of North Indians are susceptible to infection with B19.

The observation in this study that sex had no statistically significant effect on anti-B sero-prevalence among blood donors in Ayigba and Lokoja seems to be agree with the generalisation of Cennimo (2010) that parvovirus B19 infection affects males and females in equal numbers. Highest prevalence $55.1 \%$ was observed in participants within ages 20-29, followed by ages 30-39 (41.9\%) and 50-59 (33.3\%). This seems to show decrease in sero-prevalence with increase in age, which is at variance with the findings of Emiasegen $e t a l$. (2011) that reported increase in sero-prevalence with age as well as the reviews of Heegard and Brown (2002) and Kaur and Basu (2005). The difference in population of blood donors in this study as against pregnant women population in the study of Emiasegen $e t$ al. (2011) may be a factor. The findings of this study however, agree with that of Emiasegen et al. (2011) in the sense that age had no statistically significant effect on HPVB19 sero-prevalence.

Three $(75.0 \%)$ out of the four paid blood donors in the study had anti-B19 antibodies as against the $40.5 \%$ of the voluntary blood donors. Blood donors' status as paid or voluntary donors was a significant determinant of recent HPV-B19 infection with higher within status prevalence of anti-B19 IgM antibody (50.0\%) among paid blood donors. This affirms the lower quality of donor blood from paid blood donors than from voluntary blood donors.

\section{CONCLUSION}

This study showed that recipients of blood and blood products in Anyigba and Lokoja, Kogi State are at high risk $(\geq 14.8 \%$ ) of transfusion transmitted HPV-B19 infection. From the Chi-square and Pearson's correlation tests for significance, participants' status as paid or voluntary blood donor had statistically significant effect on the sero-prevalence of HPV-B19. Age and sex had no statistically significant effect on HPV-B19 sero-prevalence. The high sero-prevalence of serological markers of human parvovirus B19 infection among blood donors (a representation of healthy adults) in the study area strongly indicates the need for routine screening of blood donors in Nigeria. The findings of this study have serious implications for blood transfusion policy in Nigeria.

\section{RECOMMENDATIONS}

Considering the association of HPV-B19 with transient aplastic crisis in immunosuppressed or immunodeficient persons and individuals with underlying haemolytic disorders, and non-immune hydrops foetalis and intrauterine death, it is important to do all possible to prevent and control infection with the virus; hence the following recommendations:

[1] The National Blood Transfusion Service (NBTS) should consider routine screening of blood donors for HPV-B19 to avoid contaminated transfusion, particularly for non-immune women in the child bearing age and polytransfused individuals.

[2] The NBTS should intensify effort at total elimination of paid blood donation in the Nigerian health system.

[3] A national level sero-prevalence of human parvovirus B19 among blood donors is important and should be championed by the Federal Ministry of Health and the National Blood transfusion Service as a matter of public health concern.

\section{ACKNOWLEDGEMENT}

We thank the ethical committees of Federal Medical Centre (FMC) - Lokoja, Grimad Catholic Hospital (GCH) - Anyigba and National Blood Transfusion Service (NBTS), North Central Zonal Centre, Jos for approval, cooperation and support in the research process. The laboratory staff of these facilities gave various forms of support in sample collection, processing and assays. Statistical significance was accepted at $\mathrm{P}<0.05$ (95\% confidence level). 


\section{REFERENCES}

[1] Brooks, G. F., Carroll, K. C., Butel, J. S. and Morse, S. A. (2007). Jawetz, Melnick \& Adelberg's Medical Microbiology (Parvoviruses), 24th Edition. The McGraw-Hill Companies, Inc. ISBN-13: 978-0-07-128735-7, ISBN-10: 0-07-128735-3: 768

[2] Cennimo, D. J. (2010). Parvovirus B19 Infection. Medscape Reference Available at http://emedicine.medscape.com. Retrieved on 19-06-2011. Updated on 19-03-2010.

[3] Cossart, Y. E., Field, A. M., Cant, B. and Widdows, D. (1975). Parvovirus-like particles in human sera. Lancet i: $72-73$.

[4] Emiasegen, S. E., Nimzing, L., Adoga, M. P., Ohagenyi, A. Y. and Lekan R. (2011). Parvovirus B19 antibodies and correlates of infection in pregnant women attending an antenatal clinic in central Nigeria. Memórias do Instituto Oswaldo Cruz, 106 (2): 227231.

[5] Heegaard, E. D., Petersen, B. L., Heilmann, C. J. and Hornsleth A., (2002). Prevalence of Parvovirus B19 and Parvovirus V9 DNA and Antibodies in Paired Bone Marrow and Serum Samples from Healthy Individuals. Journal of Clinical Microbiol, 40(3): 933-936. Available at http://www.ncbi.nlm.nih.gov/pmc. Retrieved on 12-09-2011.

[6] Jordan, J. (2001). Diagnosing Human parvovirus B19 Infection: Guidelines for Test Selection. In: Human Parvovirus B19 Literature Review, 2nd Edition. Published by Biotrin International Ltd, The Rise, Mout Merrion, Co. Dublin, 3-4

[7] Kaur, P. and Basu, S. (2005). Transfusion-transmitted infections: Existing and emerging pathogens; Journal of Postgraduate Medicine, 51(2): 146-151.

[8] Kishore, J. and Kapoor, A. (2000). Erythrovirus B19 infection in humans. Indian Journal of Medical Research, 112: $149-164$.

[9] Wildig, J., Cossart, Y., Peshu, N., Gicheru, N., Tuju, J., Williams, T. N. and Newton, C. R. (2010). Parvovirus B19 infection and severe anaemia in Kenyan children: a retrospective case control study. BMC Infectious Diseases 2010. Available at http://creativecommons.org. Retrieved on 27-07-2010.

[10] Yoto, Y., Kudoh, T., Haseyama, K., Suzuki, N., Oda, T., Katoh, T. and Chiba, S. (2008). Incidence of Human Parvovirus B19 DNA Detection in Blood Donors. British Journal of Haematology, 91(4): 1017-1018. Available at www3.interscience.wiley.com/journal 